\title{
РЕФЛЕКСІЯ ЯК ПСИХОЛОГІЧНИЙ МЕХАНІЗМ МОРАЛЬНОЇ САМОРЕГУЛЯЦЇ̈ ПОВЕДІНКИ ОСОБИСТОСТІ
}

У статті розглянуто особливості моральної саморегуляиї поведінки особистості та з'ясовано роль рефлексії в ц̧ьому процесі. Науково доведено, ичо основою моральної самосвідомості, зокрема, моральних установок та переконань, виступає моральна рефлексія. 3 позицій наукових досліджень констатовано, щзо моральна рефлексія, як єдність прочесів самоусвідомлення та усвідомлення ставлення «Я-Інший», виступає провідним механізмом саморегуляцї поведінки особистості.

Ключові слова: особистість, поведінка, саморегуляція, моральні норми, моральний розвиток, моральна самосвідомість, моральна саморегулячія, рефлексія.

В статье рассмотрены особенности нравственной саморегуляции поведения личности и вылснена роль рефлексии в этом прочессе. Научно доказано, что основой нравственного самосознания, в частности, нравственных установок и убеждений, выступает моральная рефлексия. С позиций научных исследований констатировано, что моральная рефлексия, как единство процессов самосознания и осознания отношения "Я-Другой», выступает ведущим механизмом саморегуляции поведения личности.

Ключевые слова: личность, поведение, саморегуляция, моральные нормы, нравственное развитие, нравственное самосознание, нравственная саморегуляиия, рефлексия.

Постановка проблеми. Проблема становлення особистості, зокрема ii моральності, завжди була у центрі уваги соціальної та психолого-педагогічної думки. Соціально-політичні та економічні процеси, які в останні роки відбуваються у нашій країні, неоднозначно впливають на становлення суспільної свідомості людей у сфері їх духовних і моральних стосунків. Помітними стали прояви деформації в системі ціннісних орієнтацій, норм та ідеалів молодого покоління, простежується зниження значущості моральних норм і принципів, які регулюють поведінку. У дітей, підлітків та молоді проявляється посилення егоїстичних тенденцій, низький рівень розвитку моральних цінностей і почуттів, спотворення моральної мотивації. Така ситуація вимагає від закладів освіти різного типу (загальноосвітніх шкіл, гімназій, коледжів) ефективних і науково обгрунтованих впливів на свідомість та самосвідомість сучасної молоді. Значущість питань, пов'язаних 3 моральним становленням підростаючої особистості, спонукає до пошуку нових підходів у психологопедагогічному супроводі цього процесу. Психологічна наука завжди приділяла значну увагу становленню моральності особистості. Проте, передусім у психології діяльності, проблема становлення моральності розглядалася як пов'язана з соціалізацією особистості. Нині ж очевидним є, що соціалізація як така, витлумачена лише як інтеріоризація особистістю соціальних норм і поведінкових стереотипів, дуже часто призводить до формування моральної свідомості, котра не спроможна критично оцінювати негативні впливи масової культури. Утвердження моральних цінностей в індивідуальній свідомості та самосвідомості - завжди актуальна проблема психологопедагогічної науки, що відображено в завданнях сучасної освіти, зафіксованих у їі програмних документах. Саме тому нова філософія освіти спрямовується на обгрунтування гуманістичноінноваційного типу освіти, що сприятиме істотному зростанню інтелектуального, культурного та духовно-морального потенціалу особистості, їі самостійності, самодостатності, творчої активності.

Аналіз останніх досліджень і публікацій. Різноманітні питання становлення моральної й етичної свідомості знайшли відображення у психологічній літературі. Проблеми розвитку моральної свідомості та самосвідомості особистості висвітлено в багатьох працях 3 філософії та етики (Р. Азімова, Р. Апресян, А. Гусейнов, О. Дробницький, В. Малахов, О. Спіркін, О. Титаренко, О. Целікова, Д. Шимановський), педагогіки (Є. Бондаревська, В. Гурін, М. Красовицький, О. Сухомлинська, І. Харламов) та психології (І. Бех, М. Боришевський, Б. Братусь, І. Булах, І.Кон, С. Максименко, В. Москалець, М. Савчин, С. Суботський, С. Тищенко). Зокрема, у психологічній науці передумови становлення етико-моральних якостей особистості розкриті С. Максименком у рамках генетичної психології; Ю. Швалбом конкретизовано рефлексивні характеристики свідомості, зокрема й свідомості моральної, у процесі цілевизначальної діяльності; Г. Балл із раціогуманістичних позицій проаналізував взаємодію добра і зла у соціальній поведінці; О. Богданова, Т. Пироженко та ін. розглядали роль моральності у поведінці дошкільників і молодших школярів; М. Боришевський ставлення дитини до правил поведінки в ігровій ситуації; М. Савчин, В. Чудновський - 
відповідальність як етико-моральну цінність; Т. Яценко - вплив архетипів свідомості на становлення етичних образів у свідомості особистості; О. Дробницьким здійснено теоретико-методологічний аналіз поняття «мораль». Особливе значення мають концепції стадіальності морально-етичного розвитку. Це насамперед концепція Ж. Піаже, згідно з якою моральний розвиток є когнітивним за природою і пов'язаний 3 оволодінням дитиною логікою об'єктивно існуючого природного та соціального світу. Ця дослідницька парадигма відображена у працях Н. Була, К. Гілліган, У. Кейя, Л. Колберга та ін.

Аналіз наукових джерел дозволяє стверджувати, що моральна самосвідомість як одне 3 найважливіших психологічних утворень самосвідомості не $\epsilon$ стійкою структурою особистості, а іiі становлення залежить від умов ії виховання, моральної компетентності, соціального оточення (В. Аверін， А. Гармаєв， Е. Козлов， Л. Орбан-Лембрик). У моральній самосвідомості одні вчені (В. Ганжин, Г. Залєсський, О. Раєв, О. Титаренко) ставлять акцент лише на когнітивній складовій та ії змістовій наповненості, інші (В. Демиденко, К.Ізард, К. Муздибаєв, М. Савчин, В. Столін, П. Якобсон) - віддають перевагу дослідженню емоційно-ціннісної складової, зокрема, моральних почуттів, сумління, відповідальності, а ще інші (С. Анісімов, А. Вардомацький, М. Боришевський. А. Зосимовський, Г. Прихожан, Ф. Селіванов, Є. Суботський, С. Якобсон) - приділяють значну увагу поведінковій складовій моральної самосвідомості, зокрема, моральному самоконтролю, моральній саморегуляції поведінки.

Формулювання цілей статті. Наукове повідомлення присвячене аналізу особливостей моральної саморегуляції поведінки особистості та з'ясуванню ролі рефлексії у цьому процесі.

Виклад основного матеріалу дослідження. Вивчення психологічних аспектів проблеми саморегуляції діяльності та поведінки тісно пов'язане з проблемою активності особистості. Активна позиція особистості щодо обставин - це і пізнання цих обставин, і критичне вибіркове ставлення до оточуючої дійсності, що проявляється у здатності фіксувати і розв'язувати суперечності як вищій формі інтелектуальної самостійності. Необхідною умовою реалізації в діяльності та поведінці активної позиції особистості $є$ саморегуляція. 3 нею пов'язане вирішення питання про витоки активності людини, адже часто буває, що свідомо поставлена мета діяльності, не виконує своєї спонукальної функції. Як відзначає Ю.А. Міславський, фактично це питання про дієвість змістів самосвідосмості, ефективність іiі регулятивної функції [6]. Для 3'ясування сутності процесів активності та саморегуляції принципове значення має розуміння людини як суб‘єкта власного життя, висловлене в концепції С. Л. Рубінштейна [9]. Згідно з положеннями цієї концепції, людині властива свідома мотивованість дій, їх обгрунтованість, непідвладність стороннім впливам, здатність самому вбачати об‘єктивні підстави для того, щоб діяти так, а не інакше.

Здатність до саморегуляції є невід'ємною і найголовнішою характеристикою суб'єкта. Тлумачення саморегуляції в біології, фізіології, кіберенетиці як принципу зворотнього зв'язку відрізняється від розуміння саморегуляції в психології. Неправомірно розглядати саморегуляцію в психології як процес безперервного пристосування людини до умов оточуючого середовища та задоволення потреб, що виникають в даний момент. На цей момент звертає особливу увагу В.Франкл, який вважає відкритість світу основною людською якістю. Людське буття спрямоване на щось інше, що не $є$ ним самим. Тому принцип гомеостазу не може слугувати достатньою підставою для пояснення людської поведінки [12, с.55].

У сучасних дослідженнях 3 психології особистості саморегуляція розглядається як центральний компонент в структурі особистості. Так, Д.О. Леонтьєв визначає особистість як „особливу регуляторну систему, що забезпечує підпорядкування діяльності суб“єкта стійкій ієрархічній структурі відносин зі світом на противагу зовнішнім стимулам та миттєвим імпульсам" [5]. Усвідомлення та оволодіння власною поведінкою $є$ основним показником сформованості особистості за Л. С. Виготським: «Ми тільки тоді можемо говорити про формування особистості, коли наявне оволодіння власною поведінкою». Оволодіння є наслідком усвідомлення. Оволодіння власною поведінкою передбачає в якості передумови усвідомлення структури власних психічних операцій, а також «усвідомлення себе як певної цілісності суб‘єкта думки та дії» [4, с. 227]. Функції механізмів саморегуляції поведінки, за М. Й. Боришевським, виконують такі складові самосвідомості, як самооцінка, рівень домагань, соціально-психологічні очікування, образ «Я», оціночні ставлення до оточуючих. На основі перерахованих виникають і поступово включаються в якості механізмів саморегуляції поведінки такі утворення, як ідеали, переконання та інші суб'єктивно значущі еталони особистості [2]. Очевидно, що поява суб'єктивно значущих еталонів особистості можлива за умови іiі «відкритості світу» (В. Франкл), коли у неї з'являється можливість рефлексивного виходу за межі конкретної ситуації. 
Роботи С. Л. Рубінштейна та В.Франкла започаткували аналіз існування суб’єкта в світі, проблеми саморегуляції поведінки з позиції «Я та інша людина» [9; 12]. Існує група досліджень, в яких в змістовний контекст саморегуляції поведінки включаються такі елементи, як образ іншого, соціально-психологічні очікування. Поряд 3 усвідомленням «Я», яке розуміється як центр особистості, провідною підвалиною особистісної сфери є «суб' єктивна форма ставлення до інших людей, так зване ставлення Я-інший», що проявляється у вмінні співвідносити свою ситуацію і ситуацію Іншого, бажання свої і бажання іншого. Узагальнено це можна назвати здатністю «бути собою та іншим» [11]. Присутність таких елементів в моделі саморегуляції поведінки дозволяє суб'єкту відображати особистісні якості партнера по спілкуванню, враховувати їх у власній поведінці. Соціально-психологічні очікування виконують функцію врівноважування та підтримання стану збалансованості між самосвідомістю особистості та ії соціальним оточенням, виступають як чинник, що спонукає людину постійно враховувати можливі реакції з боку інших людей на дії та вчинки індивіда. Як відзначає М. Й. Боришевський, завдяки соціально-психологічним очікуванням процес саморегуляції поведінки виявляється детермінованим не тільки внутрішніми утвореннями, які складають структуру самосвідомості особистості, але й також реальним досвідом спілкування, взаємодії з оточенням [2].

Вченими доведено, що функціонування системи саморегуляції поведінки особистості забезпечуються певними психологічними механізмами, провідним серед яких $\epsilon$ рефлексія. Розглянемо особливості саморегуляції як усвідомленого управління своєю поведінкою, що дозволить 3'ясувати роль рефлексії в цьому процесі. Цілком очевидним $є$ той факт, що досягнення стану оптимальних взаємовідносин між структурними елементами саморегуляції поведінки відбувається завдяки рефлексії. Рефлексія не тільки відображає свої об'єкти, а й здатна впливати на них, конструктивно змінювати їх властивості. Це стає можливим завдяки інтеграції в індивіді функцій суб’єкта поведінки та об'єкта управління, що і забезпечує рефлексія [2]. Можна стверджувати, що особлива роль належить саморегуляції і у з'ясуванні питань морального розвитку особистості. «Якщо людина діє відповідно до існуючих стандартів, яких вона не спроможна змінити, якщо в своїй поведінці вона лише відтворює загальне правило, то така поведінка не містить морального ставлення ... специфіка природи моральності саме в тому і полягає, що вона передбачає саморегуляцію поведінки. Для людини як морального суб`єкта характерне активне ставлення до дійсності, формування власної думки про неї, регуляція поведінки на основі вимогливості до себе та відповідальності» [10]. Моральні норми як зовнішні щодо індивіда об'єкти не здатні спонукати відповідну його поведінку. Лише тоді, коли моральні норми стають внутрішнім законом, стійким, суб‘ єктивно значущим здобутком особистості, вони здатні спричиняти реальний регулятивний вплив на поведінку особистості. На думку В. Москальця, «моральні принципи і норми як скеровуючий зміст автентичної саморегуляції особистості утворюють когнітивне підгрунтя іiі моральності автентично-моральні засади іiі спрямованості, котрі функціонально виявляються у їх впливі на дії, поведінку, діяльність, спілкування людини як суб'єкта та індивідуальності» [7, с. 75].

Функціональним елементом когнітивної складової моральної самосвідомості особистості та iі саморегуляції є моральна рефлексія як здатність передбачати наслідки своїх вчинків як для інших людей, так і для себе. І. Бех підкреслює, що основою моральної самосвідомості, зокрема, моральних установок та переконань, виступає моральна рефлексія [1]. Результати досліджень І.Булах дозволили поточнити природу моральної рефлексії. Учена зазначає, що «моральна рефлексія - це осмислення і переосмислення особистістю взаємодій (діяльності, взаємин, спілкування) з точки зору належного й ціннісного, яка підносить іï на новий рівень осягнення соціального простору» [3, с. 170].На думку І. Д. Беха, виховні невдачі у розвитку здатності до саморегуляції поведінки пов'язані, перш за все, 3 невмінням дитини прийняти точку зору іншої людини. Вміння пережити та зрозуміти почуття оточуючих формується разом з самосвідомістю (образом Я та емоційно-ціннісним ставленням до себе). Подолання властивого людині егоцентризму відбувається, якщо у неї розвивається «здатність слухати іншого, оскільки ми взагалі живі тільки в тих точках, в яких проходить струм комунікації, відбувається зустріч спорідненого, злиття станів, взаємоототожнення свідомості у різних людей, а не суто логічний акт» [1] .

У формуванні позитивної концепції Іншої людини важливу роль відіграє моральна рефлексія. В ситуаціях морального вибору звернення до власного Я здійснюється не задля свого піднесення або самоствердження. Інтенсифікація рефлексії є свідченням сумнівів щодо своєї позиції або вчинку, і це підтверджує діалогічність самосвідомості людини. Рефлексія дає можливість глибокого аналізу ситуації спілкування, обгрунтування мотивації вчинків партнерів, встановлення та регулювання однакових моральних вимог щодо себе та партнера. Суб'єкту з розвиненою рефлексією властиві, перш за все сумніви щодо власної позиції та моральних якостей, прагнення до обгрунтування свого

Випуск 11, 2018. Збірник наукових праць РДГУ 
вчинку. В ситуації, що передбачає вибір між своїми інтересами та благополуччям іншої людини рефлексія дозволяє суб'єкту поглибити не тільки знання про себе, але й про психологію іншого, оцінити його стан як менш сприятливий порівняно зі своїм, робити припущення щодо можливої реакції партнера на його дії. Совість як вторинна рефлексія проявляється в формі усвідомлення значення здійснюваних вчинків щодо інших людей. Совість морально розвиненої особистості характеризує почуття незадоволеності собою, прагнення до самовдосконалення, почуття відповідальності за неблагополуччя інших людей. Таким чином, в процесі саморегуляції поведінки моральна рефлексія забезпечує функціонування усіх складових системи саморегуляції: цінностей, образу Я та самооцінки, рівня домагань та самоконтролю, концепції іншої людини. Це дозволяє вважати рефлексію провідним психологічним механізмом саморегуляції поведінки.

Моральну саморегуляцію поведінки можна розглядати як процес планування і корегування особистістю власної активності, спрямованої на успішне досягнення суб'єктивно значущих моральних цілей - допомогти, підтримати, застерегти, зрозуміти, співпереживати та ін. Характеризується вона такими специфічними особливостями: 1) головним об'єктом виступає моральний вчинок як основна одиниця моральної поведінки; 2) орієнтація особистості на вибір між добром і злом. Одним із проявів моральної саморегуляції є моральний вибір. Моральний вибір передбачає: 1) наявність двох полярних еталонів, що втілюють у конкретній формі тенденції до творення добра чи творення зла; 2) адекватне особисте ставлення до моральних еталонів; 3 ) зіставлення 3 цими еталонами не тільки окремих вчинків людини, й особистості загалом; 4) зіставлення себе і своїх вчинків з еталонами, що здійснюється самим суб'єктом.

Феноменологічно моральна саморегуляція проявляється в умінні критично оцінювати та контролювати свою поведінку, довільно спрямовувати, перебудовувати власні дії і вчинки 3 урахуванням можливих їх наслідків для себе та інших людей, у прагненні дотримуватись соціально цінних i особистісно значущих норм та правил міжособистісних стосунків тощо. Моральна саморегуляція $€$ одночасно передумовою та показником розвиненості моральної самосвідомості особистості. Важливим елементом моральної саморегуляції є самоконтроль, який належить до числа універсальних властивостей свідомості й самосвідомості та виступає як обов'язкова умова адекватного психічного відображення людиною свого внутрішнього світу і навколишньої об'єктивної реальності. Основною функцією, самоконтролю $є$ перевірка міри співпадіння між еталонами (моральними нормами, ідеалами, цінностями) та контрольованими складовими (цілями, мотивами) реалізованого морального вчинку. Сформована здатність до самоконтролю виявляється в умінні людини подивитися на себе 3 боку і можливість (якщо цього вимагає ситуація) призупинити небажану діяльність. Самоконтроль дозволяє зважувати мотиви, що передують моральному вчинку, здійснювати вибір мотивів і цілей моральних дій, керувати процесом корекції залежно від ступеня узгодженості та неузгодженості між ними. Факт неузгодженості у моральній самосвідомості особистості між мотивами і засобами досягнення цілей, реалізації конкретних моральних вчинків $\epsilon$ запускним механізмом корекції поведінки, спрямованої на гальмування, стримування неадекватних моральних дій і повернення їх у нормативне русло [10]. У ситуаціях морального вибору рефлексія $\epsilon$ не стільки зосередженням на собі, скільки засобо пізнання та об‘єктивації образу Іншої людини. Реалізація особистісно значущих цілей, яку забезпечує саморегуляція поведінки, передбачає в першу чергу, не власне благо, а благо іншої людини, яка сприймається як цілісна особистість. Підкреслимо ще раз, що це не означає ігнорування власних інтересів. Навпаки, суб'єкт - суб'єктні відносини передбачають психологічну єдність партнерів, у якій розгортається їх творче взаємозбагачення. Такі відносини передбачають емоційну й особистісну відкритість партнерів, психологічну налаштованість на актуальний стан один одного, щирість, довіру і безпосередність у вияві почуттів та душевних станів. Необхідною умовою суб’єктного сприймання Іншої людини є моральна рефлексія. Вона дозволяє людині відчувати себе суб'єктом власної активності, волі, переживань. Власне Я при цьому виступає як унікальне, а це робить можливим таке ж сприймання Іншого як унікальної особистості.

Другим важливим завданням рефлексії є іiї здатність зробити людське Я об'єктом власного дослідження та управління. Так формуються уявлення людини про свої моральні якості, можливості, їх оцінка та значущість. Інша людина при цьому також постає у якості об‘єкта, оскільки пізнання якостей іншого та їх порівняння зі своїми власними дозволяє людині окреслити межі свого Я, свого власного внутрішнього світу, усвідомити свої відмінності від інших. Обидві функції рефлексії $\epsilon$ взаємопов'язаними і необхідними у будь-якій ситуації морального вибору. Розвинена моральна рефлексія гармонізує сферу спонук індивіда, дозволяє реалізувати альтруїстичну поведінку, не відчуваючи при цьому психологічної напруги. Моральна рефлексія формується на основі переконань, що складаються в процесі моральної діяльності, i, у свою чергу, сприяє їхньому подальшому оформленню в єдину систему. Моральна рефлексія породжує внутрішній діалог із самим собою, 
змістом якого є моральна проблематика - Я-моральне. Але слід зауважити, що особистість більшою мірою виявляють інтерес до вивчення свого внутрішнього світу, ніж до аналізу моральних аспектів життєвих ситуацій. Це насамперед перегляд i лібералізація ціннісних уявлень, на основі яких формуються наступні здібності: а) застосування до самого себе тих же критеріїв оцінки, що і до інших; б) використання загальних принципів моральної поведінки як основи оцінювання себе й інших; в) здатність враховувати потреби, інтереси і почуття інших так само, як свої власні [8].

Висновки та перспективи подальших досліджень. Мораль $є$ способом регуляції життєвих стосунків, що вимагає від особистості самостійно визначати лінію своєї поведінки щодо інших людей, виходячи 3 рівня сформованості моральної свідомості. Її суть полягає в тому, що вона відбувається шляхом подолання суперечностей між суб'єктом і об'єктом, коли загальне не протиставляється особистому, а особисте - загальному. За своєю природою моральна регуляція - це саморегуляція, коли особистість повинна не лише знати моральні вимоги, моральні норми і формально їх дотримуватися, а усвідомлювати, приймати, відчувати об'єктивну необхідність і бачити особистісний смисл цих моральних вимог, приймати їх як свої власні. Суттєва особливість моральної регуляції - єдність об'єктивного значення й особистісного смислу моральної вимоги, в ідеалі - їх співпадання. Людина дотримується моральних норм, вона переконана у їх необхідності, об'єктивній та суб'єктивній значущості. Одночасно, моральна рефлексія як єдність процесів самоусвідомлення та усвідомлення ставлення «Я-Інший» виступає провідним механізмом саморегуляції поведінки. Завдяки моральній рефлексії людина має можливість оцінити ситуацію особистісної взаємодії, оцінити свій стан та стан свого партнера з позицій моральних цінностей.

\section{Список використаних джерел}

1. Бех І. Д. Виховання особистості : сходження до духовності / І. Д. Бех. - Київ : Либідь, 2006. $-272 \mathrm{c}$.

2. Боришевський М. Й. Психологічні механізми розвитку особистості / М. Й. Боришевський // Педагогіка і психологія. - 1996. - № 3. - С. 26-33.

3. Булах І. С. Психологія особистісного зростання підлітка : монографія / І. С. Булах. - Київ : НПУ імені М. П. Драгоманова, 2003. - 340 с.

4. Выготский Л. С. Психология развития человека / Л. С. Выготский. - М. : Смысл, Эксмо, 2005. $-1136 \mathrm{c}$.

5. Леонтьев Д. А. Психология смысла: природа, строение, динамика смысловой реальности / Д. А. Леонтьев. - М. : Смысл, 1999. - 487 с.

6. Миславский Ю. А. Саморегуляция и активность личности в юношеском воздасте / Ю. А. Миславский. -М. : Педагогика, 1991. - 152 с.

7. Москалець В. Духовні горизонти особистості: потенціал вершинної аналітики / В. Москалець // Психологія і суспільство. - 2011. - № 1. - С. 73-84.

8. Павелків Р. В. Розвиток моральної свідомості та самосвідомості у дитячому віці : [монографія] / Р. В. Павелків. - Рівне : Волин. обереги, 2004. - 248 с. $713 \mathrm{c}$.

9. Рубинштейн С. Л. Основы общей психологии / С. Л. Рубинштейн. - СПб. : Питер, 2006. -

10. Моральна свідомість та самосвідомість особистості як предмет психологічного аналізу : монографія / М. В. Савчина, О. І. Галян, Л. П. Василенко та ін. - Дрогобич, 2009. - 288 с.

11. Славская А. А. Соотношение эгоцентризма и альтруизма личности : интерпретации / А. А. Славская // Психологический журнал. - 1999. - Т. 20, № 6. - С. 13-23.

12. Франкл В. Человек в поисках смысла / В. Франкл. - М. : Прогресс, 1990. - 387 с.

\section{References:}

1. Bekh I. D. Vykhovannya osobystosti : skhodzhennya do dukhovnosti / I. D. Bekh. - Kyyiv : Lybid, 2006. - $272 \mathrm{~s}$.

2. Boryshevs'kyy M. Y. Psykholohichni mekhanizmy rozvytku osobystosti / M. Y. Boryshevs'kyy // Pedahohika i psykholohiya. - 1996. - № 3. - S. 26-33.

3. Bulakh I. S. Psykholohiya osobystisnoho zrostannya pidlitka : monohrafiya / I. S. Bulakh. Kyyiv : NPU imeni M. P. Drahomanova, 2003. - 340 s. $-1136 \mathrm{~s}$.

4. Vygotskiy L. S. Psikhologiya razvitiya cheloveka / L. S. Vygotskiy. - M. : Smysl, Eksmo, 2005.

5. Leont'yev D. A. Psikhologiya smysla: priroda, stroyeniye, dinamika smyslovoy real'nosti / D. A. Leont'yev. - M. : Smysl, 1999. - 487 s. 
6. Mislavskiy YU. A. Samoregulyatsiya i aktivnost' lichnosti v yunosheskom vozdaste / YU. A. Mislavskiy. -M. : Pedagogika, 1991. - $152 \mathrm{~s}$.

7. Moskalets' V. Dukhovni horyzonty osobystosti: potentsial vershynnoyi analityky / V. Moskalets // Psykholohiya i suspil’stvo. - 2011. - № 1. - S. 73-84.

8. Pavelkiv R. V. Rozvytok moral'noyi svidomosti ta samosvidomosti u dytyachomu vitsi : [monohrafiya] / R. V. Pavelkiv. - Rivne : Volyn. oberehy, 2004. - 248 s.

9. Rubinshteyn S. L. Osnovy obshchey psikhologii / S. L. Rubinshteyn. - SPb. : Piter, 2006. - 713 S.

10. Moral'na svidomist' ta samosvidomist' osobystosti yak predmet psykholohichnoho analizu : monohrafiya / M. V. Savchyna, O. I. Halyan, L. P. Vasylenko. - Drohobych, 2009. - 288 s.

11. Slavskaya A. A. Sootnosheniye egotsentrizma i al'truizma lichnosti : interpretatsii / A. A. Slavskaya // Psikhologicheskiy zhurnal. - 1999. - T. 20, № 6. - S. 13-23.

12. Frankl V. Chelovek v poiskakh smysla / V. Frankl. - M. : Progress, 1990. - 387 s.

R.V.Pavelkiv. REFLECTION AS A PSYCHOLOGICAL MECHANISM OF MORAL SELFREGULATION OF PERSONALITY'S BEHAVIOUR.

The article deals with the psychological aspects of the problem of self-regulation of activity and behaviour in the context of the moral development of a personality. In the study of the essence of the processes of activity and self-regulation of the personality's moral behaviour the significance of the understanding of the person as the subject of his/her own life, who is consciously motivated by actions, their validity and non-subordination to external influences is clarified. From the standpoint of the modern psychological research of the person it has been stated that the self-regulation is considered as a central component in the structure of the personality, and awareness and mastery of their own behaviour is the main indicator of the formation of the individual.

It has been proved that the functioning of the system of self-regulation of the personality's behaviour is provided by certain psychological mechanisms, the leading among them is the reflection, which is the cognitive component of the moral self-consciousness of the individual, and lies at the basis of the ability to predict the consequences of their actions for other people and for themselves as well. In general, it has been found out that the developed moral reflection harmonizes the sphere of the individual's motive, allows him to realize altruistic behaviour without experiencing the psychological stress. Moral reflection is formed on the basis of the beliefs that are formed in the process of the moral activity, and, in its turn, contributes to their subsequent registration into the united system.

Key words: a personality, behaviour, self-regulation, moral norms, moral development, moral selfconsciousness, moral self-regulation, reflection. 